Meta

Journal des traducteurs

Translators' Journal

\title{
Intralingual Translation: An Attempt at Description
}

\section{Karen Korning Zethsen}

Volume 54, numéro 4, décembre 2009

URI : https://id.erudit.org/iderudit/038904ar

DOI : https://doi.org/10.7202/038904ar

Aller au sommaire du numéro

\section{Éditeur(s)}

Les Presses de l'Université de Montréal

ISSN

0026-0452 (imprimé)

1492-1421 (numérique)

Découvrir la revue

Citer cet article

Zethsen, K. K. (2009). Intralingual Translation: An Attempt at Description. Meta, 54(4), 795-812. https://doi.org/10.7202/038904ar

\section{Résumé de l'article}

En théorie, la traductologie n'exclut pas la traduction intralinguale, mais, dans les faits, les études empiriques ou les essais sur ce thème sont peu courantes. Dans le présent article, nous soutenons que la traduction intralinguale doit faire partie intégrante de la traductologie en raison de ses multiples similarités avec la traduction interlinguale. À titre de comparaison, il est proposé une description générale de la traduction interlinguale et de ses caractéristiques sur la base de cinq versions danoises différentes d'une même section de la Bible et d'une analyse des micro-stratégies à l'oeuvre dans chacune de ces versions. Les similarités aussi bien que les différences entre reformulation et traduction proprement dite seront discutées, la conclusion étant que les différences entre traductions intralinguale et interlinguale semblent être une question de degré plus que de nature.
Ce document est protégé par la loi sur le droit d'auteur. L'utilisation des services d'Érudit (y compris la reproduction) est assujettie à sa politique d'utilisation que vous pouvez consulter en ligne.

https://apropos.erudit.org/fr/usagers/politique-dutilisation/ 


\title{
Intralingual Translation: An Attempt at Description
}

\author{
KAREN KORNING ZETHSEN \\ University of Aarhus, Aarhus, Denmark \\ kkz@asb.dk
}

\begin{abstract}
RÉSUMÉ
En théorie, la traductologie n'exclut pas la traduction intralinguale, mais, dans les faits, les études empiriques ou les essais sur ce thème sont peu courantes. Dans le présent article, nous soutenons que la traduction intralinguale doit faire partie intégrante de la traductologie en raison de ses multiples similarités avec la traduction interlinguale. À titre de comparaison, il est proposé une description générale de la traduction interlinguale et de ses caractéristiques sur la base de cinq versions danoises différentes d'une même section de la Bible et d'une analyse des micro-stratégies à l'œuvre dans chacune de ces versions. Les similarités aussi bien que les différences entre reformulation et traduction proprement dite seront discutées, la conclusion étant que les différences entre traductions intralinguale et interlinguale semblent être une question de degré plus que de nature.
\end{abstract}

\begin{abstract}
In theory, translation studies does not exclude intralingual translation, but de facto empirical studies or discussions on the subject of intralingual translation are few and far between. This article argues for the proper inclusion of intralingual translation on the grounds of its many similarities with interlingual translation. For the sake of comparison, a general description of intralingual translation and its characteristics on the basis of five different Danish versions of a section of the Bible and an analysis of the microstrategies employed in each version are proposed. Similarities as well as differences between rewording and translation proper are discussed, the conclusion being that the differences between intralingual and interlingual translation seem to be more a question of degree than of kind.
\end{abstract}

\section{MOTS-CLÉS/KEYWORDS}

traduction intralinguale, traduction interlinguale, études empiriques, micro-stratégies intralingual translation, interlingual translation, empirical studies, microstrategies

\section{Introduction}

For a number of years I have carried out research within medical expert-to-layman communication (in addition to my work within translation proper) and as a translation scholar been intrigued by the many similarities between interlingual and intralingual translation. However, despite Jakobson's classical definition, intralingual translation or rewording is extremely peripheral to translation studies, more so than it deserves, and the relationship between interlingual and intralingual translation is a neglected area of research, as is a thorough description of intralingual translation; it is next to impossible to find any relevant literature.

In the preface to the Routledge Encyclopedia of Translation Studies, Baker also, 
argues that we have been narrow and restrictive in defining our object of study and expresses concern about the lack of research outside the field of translation proper:

[...] intralingual translation is not such a minor issue as the existing literature on translation might suggest...I know of no research that looks specifically at the phenomena of intralingual or intersemiotic translation. We do have classifications such as Jakobson's, which alert us to the possibility of such things as intersemiotic and intralingual translation, but we do not make any genuine use of such classifications in our research (my emphasis; Baker 1998: xvii).

Modern high-tech society with its international cooperation and intercultural communication in business as well as in political and cultural life has led to demands for many different kinds of translation or translation-like activities which often exceed the boundaries of what translation theory traditionally terms translation proper. Highly functional translations (which meet skopoi which differ greatly from those of the source texts), localisation, précis-writing, expert-to-layman communication, etc. are all part of modern life, of reality. However, I have never seen a detailed, empirically-based attempt to describe the general characteristics of intralingual translation and the strategies employed or compare it with interlingual translation. Within polysystem theory and the realms of literary translation (Even-Zohar 1990) we do find some work on intralingual or intersemiotic translation (Weissbrod 1998, 2004; Shavit 1986). Translation (whether interlingual, intralingual or intersemiotic) is seen as part of the semiotic concept of transfer and special focus is on transfer from one culture to another. According to Weissbrod (2004: 24), reflecting the views of Even-Zohar, researchers should deal with all these examples of transfer within one theoretical framework as the mechanism of transfer is largely the same in all instances.

My initial research into the nature of intralingual translation (see Zethsen 2008) made me aware of the fact that since the time of Jakobson's definition, general definitions of translation have become less inclusive. This I think is a major setback as there seems to be much to gain theoretically as well as practically by looking for similarities and differences between the various kinds of translational activities carried out. Even-Zohar (in Weissbrod 2004: 24) argues that "there is no benefit in dealing with one phenomenon (translation) as if it were detached from other phenomena when it is not." And Gambier (1992: 308) takes a similar view: "Enfin, il oblige à reposer la nécessité prétendue d'une théorie de la traduction, autonome, séparée de la théorisation des autres processus interactionnels (intralinguistiques)."

With the ulterior motive of putting intralingual translation (back?) on the map of translation studies and encourage future empirical research the aim of the present article is to take a closer look at intralingual translation in order to describe this kind of translation and the strategies involved and to compare it with translation proper. To this end, five different versions of the same text have been analysed. Throughout the article the discussion will rely on an open definition of translation which reflects the many-faceted nature of the activity.

\section{Defining translation}

Translation studies is engaged in the academic study of translation and it is therefore common that works on translation devote chapters or paragraphs to a definition of 
translation as a concept. Intuitively even laymen would know what a translation is and would probably define it in a way which corresponds to the prototypical translation proper in Jakobson's terminology. Many translation scholars rely on Jakobson's three kinds of translation for their definitions of what constitutes translation, but de facto they mostly focus exclusively on Jakobson's concept of interlingual translation. In his Dictionary of Translation Studies, Shuttleworth (1997: 82) writes that interlingual translation is the only kind of translation which corresponds to what is normally understood by the word translation. Jakobson builds on Pierce's theory of signs and meaning and postulates that "the meaning of any linguistic sign is its translation into some further, alternative sign" (Jakobson 1959/2000: 114). The implication is that translation is a component in all language transactions and Jakobson divides these transactions into three kinds of translation or "ways of interpreting a verbal sign":

- intralingual translation or rewording is an interpretation of verbal signs by means of other signs of the same language;

- interlingual translation or translation proper is an interpretation of verbal signs by means of some other language;

- intersemiotic translation or transmutation is an interpretation of verbal signs by means of signs of nonverbal sign systems.

(Jakobson 1959/2000: 114)

Interlingual translation, or translation proper, is seen naturally enough also by translation scholars as the classic, prototypical kind of translation and many scholars even want to limit research to very restricted definitions of translation proper (Tymoczko 2005: 1096, footnote 3). Even though translation scholars mention and acknowledge Jakobson's other kinds of translation these are often classified as peripheral or de facto considered of no real relevance to the discipline of translation studies. Once Jakobson's seminal text - with its very broad philosophical and hermeneutic definition of translation - has served its purpose of defining translation, authors quickly move on to the field of translation proper, or to the restricted area of translation proper which has their particular interest.

Jakobson argued for a broad, inclusive definition of translation as a phenomenon fundamental to all language transactions. This line of thought was further elaborated by Steiner in 1975. To Steiner, translation proper is seen as a heightened case of the process of communication and reception, but he also claims that the linguistic problems implicit in interlingual translation are already implicit in all intralingual discourse (Steiner 1975: 260-261, 414) - a view reflected by Even-Zohar in 1990 when discussing the mechanism of transfer (see also Weissbrod 2004: 24; Shuttleworth 1997: 88). Again Steiner builds on Jakobson who also discussed, for instance, the fact that the challenge of synonymy in intralingual translation resembles the challenge of equivalence in interlingual translation (Jakobson 1959/2000: 114; Shuttleworth 1997: 88; Dam-Jensen and Zethsen, 2008). Complete equivalence as well as absolute synonymy is very rare (if it exists at all) and this fundamental dilemma of interpretation is shared by rewording as well as translation proper (Steiner 1975: 261): "What Jakobson calls 'rewording' - an interpretation of verbal signs by means of other signs in the same language - in fact raises issues of the same order as translation proper" (Steiner 1975: 414).

In spite of the highly influential texts of Jakobson and Steiner and in spite of their claim of close affinity between interlingual and intralingual translation, translation 
studies often excludes intralingual translation either deliberately or de facto. Gutt (1991/2000: 394-396) mentions the fact that not all translation scholars would feel comfortable with a broader definition which would allow summaries and elaborated versions, per example, to qualify as translation. Newmark, as a case in point, would consider such activities to be what he terms restricted translation falling outside the scope of translation theory proper (Gutt 1991/2000: 394; Newmark 1981: 12). Newmark's definition (1999) is very narrow indeed; it includes only translation proper and strongly relies on the much criticised concept of equivalence (SnellHornby 1988; Zethsen 2004). In other words, Newmark's definition leaves no room for changing skopoi or intralingual translation and it implies that the field of translation studies is not open to insights originating from other kinds of translation than translation proper. Newmark's definition may be prototypical for him and many others, but it does not necessarily represent translational reality today. This is discussed by Snell-Hornby $(1999,2006)$ who heavily criticises and warns against a too narrow perception of translation (in general, and Newmark's definition in particular) - "the traditional linguistic transcoding activity" (Snell-Hornby 1999: 164) - and of the tasks of the modern-day translator, which need to be reflected to some extent in our theoretical discussions if they are to remain meaningful. Also Schäffner points out that translational reality exceeds interlingual translation and she claims that it is increasingly agreed within the academic community of translators that "the translator's responsibilities go well beyond what was traditionally considered a 'translation proper”' (Schäffner 1999: 98). Schäffner (1999: 100) relevantly asks whether translation itself is affected by modern developments "or is it rather that more and more activities are added to translation proper? Where does translation stop and something else take over, e.g. technical writing, or desktop publishing?" and whether this means that we would have to redefine the very notion of translation. I think we do need to redefine, even though we might actually ask "redefine what?" as there is no consensus within translation studies about one particular definition.

Even on the basis of a hermeneutic approach it still makes sense to try to delimit the field of translation studies, the question is in which way?

\subsection{An open definition of translation}

A recent article (Zethsen 2008) examined Toury's very influential and highly pragmatic definition of translation relying on the concept of assumed translation ${ }^{1}$ and his three postulates ${ }^{2}$ (Toury 1985, 1995) and the conclusion was that all three postulates are equally relevant to intralingual translation, but that Toury's definition though attractive - would not be able to contain intralingual translation mainly because of the requirement of assumed translation. An alternative definition starting from Toury's three postulates was suggested, but inspired by Tymoczko ${ }^{3}(1998,2005)$ relying on Wittgenstein's theory of family resemblances (1953/1958) and Rosch's protypology (1973). My alternative definition is open and inherently non-finite and is an attempt to define the discipline of translation studies as an open field which relies on an open, inherently non-finite, yet describable concept and not on necessary or sufficient conditions or audience assumptions. According to Shuttleworth (1997: 88), Jakobson, by producing his three categories, simply suggested that translation belongs to a group of interlinked phenomena between which one can find "family 
resemblances" and Tymoczko $(1998,2005)$ argues for a broad perception of translation and suggests that we regard translation as a cluster concept which has to be defined non-finitely in line with Wittgenstein's concept of family resemblance. Arguing against the classical theory of categorisation, which involves shared properties as conditions for category membership, strictly objective conditions for category membership and clear boundaries between categories, i.e., no borderline cases (in logic the specification of necessary and/or sufficient conditions is used to determine category membership, to provide precise definitions), Wittgenstein introduced the very pragmatic and empirically-based (that is, not on formal logic) open concept of family resemblances (also called the cluster concept) and argued that this is what unites the category of game, for instance (Wittgenstein 1953/1958: section 66-67). If we regard translation as a cluster concept, i.e., as an open concept, our requirements for category membership do not take the form of necessary conditions, but family resemblances; "sometimes overall similarities, sometimes similarities of detail" which "overlap and criss-cross" (Wittgenstein 1953/1958: section 66-67) in the same way as resemblances between members of a family. That the definition of certain concepts needs to be open is simply an inherent feature of such concepts; in other words it is not a flaw or deficiency that some concepts cannot be finitely described, neither theoretically nor pragmatically.

On the basis of these insights, I attempted to set up an alternative definition of translation which is able to contain a wide range of translational phenomena, including that of intralingual translation, but which is still narrow enough to be meaningful to the field of translation studies. If we accept that translation can only be accounted for in a meaningful way if we treat it as a cluster concept, it does not make sense to attempt a too finite description. Toury's definition is likely to exclude many intralingual (or intersemiotic) translations, not because of his three postulates, which themselves rely on open concepts, namely source text, transfer and intertextual relationship, but because of two necessary conditions; to constitute a translation a transfer process must have taken place between two languages/cultures and most importantly the resulting product must be assumed to be a translation by people in general. In my view neither of these two requirements are necessary conditions for a document/ product to constitute a translation and they would effectively exclude all intralingual translation. However, none of Toury's three postulates constitute a problem to either intralingual or intersemiotic translation. What they offer is a description of the fundamental activity of translation, but a description which relies on open concepts and which is therefore able and willing to include a whole range of examples, from the prototypical to the peripheral, depending on the distance in question from the prototypical definition of the concepts involved. I think it is possible to describe translation (and not finitely define it) by means of Jakobson's three dimensions in combination with Toury's more specific description of a source text and a transfer. In this way we are able to reach a broad though still meaningful description of translation, relevant to the field of translation studies, which does not exclude, in particular, intralingual translation:

A source text exists or has existed at some point in time. A transfer has taken place and the target text has been derived from the source text (resulting in a new product in another language, genre or medium), i.e. some kind of relevant similarity exists between the source and the target texts. This relationship can take many forms and 
by no means rests on the concept of equivalence, but rather on the skopos of the target text.

The above constitutes a description of translation which, though not as broad as Steiner's all-embracing hermeneutic approach, still sees the phenomenon of translation as much more fundamental to human communication than more traditional translation studies definitions. However, nothing in the description should be considered necessary or sufficient to define translation. The aim of the description is to function as a tertium comparationes when trying to determine family resemblances.

\section{An attempt at description: intralingual translation}

As we have seen above, Jakobson's definition of intralingual translation partly lies in its other name, rewording, and partly in the more explicit explanation offered by Jakobson: an interpretation of verbal signs by means of other signs of the same language. This definition is quite clear, but unlike the case of translation proper where numerous efforts are made to further define and exemplify what constitutes translation proper in the real world, it is not possible to find more than stray sentences as regards intralingual translation. In practice, we see many kinds of intralingual translation; numerous varieties of expert-to-layman communication, easy-readers for children, subtitling for the deaf, summaries, some kinds of news reporting, new translations of classics, etc. (see Shuttleworth 1997: 87-88 and Gambier 1992 for more examples - as one of the few, Gambier actually writes about intralingual translation, but though interesting, the article is not based on empirical work and does not compare with interlingual translation). As argued above, these activities share family resemblances with translation proper, but is it possible to get closer to a more detailed account of their general characteristics? And in which ways do they differ from or resemble translation proper? Holmes (1972/2000) encourages us to describe, explain and predict, but to my knowledge the literature does not offer a systematic empirically-based account of intralingual translation, so this is what will be attempted in the following. It should be emphasized that it is an attempt, at a more detailed general description as there is not much theory or any empirical studies to lean on.

\subsection{Case study: five versions of the same text}

Even though the empirical study of intralingual translation is meagre, no one can deny that intralingual translation is a widespread phenomenon and that it is easy to find many very different instances of this kind of translation (within expert-layman communication, for instance, they abound). When planning this case study, a number of different examples of intralingual translation were considered. However, my aim was not to describe intralingual translation within a limited area, but to attempt a general characterisation of the phenomenon through the microstrategies used in creating the new versions. To this end, the goal was to find a text which exists in many (available) versions and the Bible was an obvious choice - it allows the study of a whole range of intralingual translations originating from the same basic content. The Bible as a source text is a complicated matter though because of the interlingual translation which is also involved. The authorised versions in Danish which have been produced through the times are translated from Greek (New Testament) and 
Hebrew (Old Testament), but the translators quite naturally consult translations into e.g. English, German, French, Swedish and Norwegian as well as other Danish versions (Jeppesen 1990: 23-24). The version for very small children which is analysed is based on an English-language version (The Beginners Bible) and in the case of the New Testament in everyday Danish, the translators state in its preface that they have consulted several new foreign versions, especially The Living Bible in English, but that the Danish translation is considerably closer to the source text than the former. Many versions in many languages may be involved in Bible translation, but from the point of view of this article the interesting fact is that different versions of the Bible, of the same basic message, are created in order to cater for various target groups. It is this basic message which is intralingually translated into new versions, irrespective of the element (small or great) of interlingual translation - intralingual translation is crucial in each new version.

In the English-speaking world the authoritative version is the King James Bible from 1611 (basically unrevised from that date if spelling and punctuation is discounted, see Nicolson 2003/2004) and in Denmark the first authorised version of the New Testament translated from Greek came in 1907 though the most influential work in Danish Bible translation is the resen-svanningske translation from 1647 on which the authorised version is based (Jeppesen 1990: 18) (the 1907 authorised version has since been revised in $1948^{4}$ and $1992^{5}$ ).

I have chosen to analyse and compare four different Danish versions of five verses from Luke chapter 2 with the Danish authorised 1948 version and this is how they read in the King James version (a 1986 edition $^{6}$ ):

[3] And all went to be taxed, every one into his own city.

[4] And Joseph also went up from Galilee, out of the city of Nazareth, into Judaea, unto the city of David, which is called Bethlehem; (because he was of the house and lineage of David:)

[5] To be taxed with Mary his espoused wife, being great with child.

[6] And so it was, that, while they were there, the days were accomplished that she should be delivered.

[7] And she brought forth her firstborn son, and wrapped him in swaddling clothes, and laid him in a manger; because there was no room for them in the inn.

Though the Danish 1948 version has not been translated from King James, but from Greek, it reads as an almost direct translation thereof (92 words):

[3] Og alle gik hen for at lade sig indskrive, hver til sin by.

[4] Og fordi Josef var af Davids hus og slægt, drog også han op fra op fra Galilæa, fra byen Nazaret, til Judæa, til Davids by, som hedder Betlehem,

[5] for at lade sig indskrive tillige med Maria, sin trolovede, som var frugtsommelig.

[6] Og det skete, medens de var der, kom tiden, da hun skulle føde.

[7] Og hun fødte sin søn, den førstefødte, og svøbte ham og lagde ham i en krybbe, thi der var ikke plads til dem i herberget.

The four intralingual translations into Danish are the following in chronological order:

1) A family picture Bible from $1973^{7}$ (236 words)

2) A picture Bible for very small children from $1991^{8}$ (158 words)

3) The Danish authorised version from 1992 (88 words)

4) The New Testament in everyday Danish from $1985 / 2002^{9}$ (89 words) 
Where necessary, examples have been translated from the Danish versions into English. In some examples, the translation is not idiomatic, but direct, in order to illustrate what has taken place.

\subsubsection{A family picture Bible from 1973}

The target group for this text is families, especially young people and children. The first thing that springs to mind when comparing the family picture Bible from 1973 with the authorised version from 1948 is the high number of words in the family version, namely 236 compared to 92 words in the 1948 version. A closer look reveals that the extended number of words comes from a large number of factual explanations and the addition of factual information to enhance children's understanding of the text.

(1) Objective additions

[...] to be taxed in the city from which their people originally came.

It can be very cold outside in the winter in Judaea [...].

[...] because it is always warm in a stable with animals, especially if they are cows.

However, the extension also comes from subjective additions to the text, presumably to make it come more alive to children, but also in a few instances to vent the translator's own views.

(2) Subjective additions

[...] and Joseph was happy that they could get inside where it was warm [...].

$[\ldots]$ and then the bed was as soft and as clean as you could ask for.

There he was, warm and comfortable like his mother in the stall.

(3) Subjective comments from the translator

It was very uncomfortable for them to travel as Maria was soon to give birth; but of course those in power do not ask about such things.

Joseph swept the floor [...].

$[\ldots]$ and Joseph made a bed for the child in the manger.

The subjective comments in the above examples reflect a political/feminist agenda from the 1970s. There are only two omissions in the text; the name Nazareth and the fact that Joseph and Maria were engaged. Almost all of the text has been paraphrased and as could be expected lexis and syntax have been simplified in the process. Practically all information has been transferred, but the order of the information has been changed in quite a few instances and pictures have been added. All in all, the changes made centre around the level of background knowledge (cultural as well as factual) and ability of comprehension of the target group. The aim is to make the text understandable and interesting especially to the young members of a family. ${ }^{10}$

\subsubsection{A picture Bible for very small children from 1991}

The target group for this text is children from 3 to 5 years old. The picture Bible for very small children from 1991 is naturally very different from the 1948 authorised version, but in many ways resembles the family Bible for children from 1973 as regards explanations, explicitations, lexical and syntactical simplification, the addition of pictures as well as textual additions to enhance children's comprehension of 
and interest in the text (with one exception though: all additions are factual, i.e., objective). Two features differ significantly from all the other intralingual translations, including the other Bible for children, namely firstly the fact that the structure of the text has been changed radically and does not follow the traditional structure (restructuring of the order of information is also seen in the family Bible from 1973, but in this version for very small children the restructuring is much more radical) and secondly that quite a number of content omissions have been made. The text has been extended to 158 words though this includes verse 1 because of the restructuring. The entire text is one long paraphrase, not a single phrase is identical to the 1948 version.

(4) Structural changes

Nu elskede Maria en mand, som hed Josef. De skulle snart giftes.

Now Maria loved a man called Joseph. They were soon to be married.

This is how the text starts, but the information about Joseph and Maria being engaged is traditionally not given until later in the text. Then follows the sentence:

Kejseren ville tælle folk i de byer, de var født i.

The emperor wanted to count people in the cities in which they were born.

This sentence is originally from the first verse. Early in this small children's version we are also told that Joseph and Maria tried to find somewhere to stay, but that there was not room in any of the houses ("Josef og Maria forsøgte at finde et sted, hvor de kunne være, men der var ikke plads i et eneste af husene”), though the 1948 version does not give this information until the last sentence where we are told that Maria laid her son in a manger "because there was no room for them in the inn."

Maria og Josef gav ham navnet Jesus, sådan som englen havde sagt de skulle.

Maria and Joseph gave him the name Jesus, just as the angel had told them to.

This sentence provides information which is traditionally not given until verse 21 .

(5) Omissions

The only thing that remains from verse 4 "And Joseph also went up from Galilee, out of the city of Nazareth, into Judaea, unto the city of David, which is called Bethlehem; (because he was of the house and lineage of David)" is the fact that Joseph and Maria are going to Bethlehem, everything else has been omitted. The facts that Maria was with child and that the child was her firstborn have been left out.

The changes made centre around the level of background knowledge and ability of comprehension of the target group. The aim of this version is to get even very young children to understand and take an interest in the main message of the text.

\subsubsection{The Danish authorised version from 1992}

The target group is adults who prefer a traditional, formal version. The 1992 version is allegedly a new translation from Greek, but as mentioned above the translators do of course consult other modern language versions and in this case have leaned heavily on the 1948 version. Not surprisingly, the Danish authorised version from 1992 resembles the authorised version from 1948. The length is almost the same, namely 88 words. Nothing has been added and nothing has been paraphrased. The only changes are the following: lexical changes consisting of synonymous expressions (all 
absolute synonyms apart from the diachronic aspect) making the language more contemporary:

(6) Old words and expressions replaced by contemporary ones

1948 tillige (together with)

1992 sammen med

1948 trolovede (betrothed)

1992 forlovede

1948 frugtsommelig (with child)

1992 ventede et barn

1948 medens (while)

1992 mens (more modern spelling)

1948 thi (because)

1992 for

In one instance, the newer version replaces a modern-sounding expression Gik hen (went up to) with an older one, namely Drog hen, but probably because Drog hen is the more semantically correct expression.

(7) Syntactical changes making the text more contemporary

(a)

1948 Og fordi Josef var af Davids hus og slægt, drog også han op fra...

And because Joseph was of the house and lineage of David, also he went up from [...]

1992 Også Josef drog op fra...fordi han var af Davids hus og slægt... Also Joseph went up from... because he was of the house and lineage of David [...]

(b)

1948 Og det skete, medens de var der, kom tiden, da hun skulle føde And it happened, while they were there, came the time, when she were to give birth

1992 Og mens de var dér, kom tiden, da hun skulle føde And while they were there, came the time, when she were to give birth

The content has remained constant both denotatively and connotatively. Contemporary synonyms have replaced older ones and a more modern and less stilted syntax has been used. The changes made centre around the difference in time between the two versions and the aim is to make a traditional, close translation/version gently brought up to date to make it more accessible to contemporary readers.

\subsubsection{The New Testament in everyday Danish from 1985/2002}

The target group is adults who find the authorised version too difficult or stilted. The New Testament in everyday Danish from 1985/2002 (the five verses analysed are exactly the same in both editions) resembles the authorised version from 1948 (and the one from 1992) in both length and content. Unlike the other versions, the New Testament in everyday Danish has a preface in which the translators explain their strategy:

You cannot blindly translate from source language to target language without disturbing the original meaning. We therefore acknowledge our responsibility in the editorial interpretation of the source text... The translation is thus a free translation, neither a word-for-word translation, nor a paraphrase. ${ }^{11}$ 
This strategy is clearly reflected in the translation. Close attention has been paid to the authorised version, no major additions or paraphrasing have taken place, though some explicitation has been made (objective additions). At the same time more contemporary words and expressions have replaced older ones (several resembling the changes which were later to be made in the authorised version from 1992), everyday words have replaced more formal language and the syntax has become more straightforward resembling spoken language.

(8) Explicitation

1948 indskrive (register)

2002 indskrive på mandtalslisterne (register on the census)

1948 hver til sin by (each to his town)

2002 i den by, de stammede fra (in the town from which they came)

1948 David (David)

2002 Kong David (King David)

1948 svøbte ham (wrapped him)

2002 svøbte ham i et tæppe (wrapped him in a blanket)

(9) Everyday language instead of formal or archaic language

1948 af Davids hus og slægt (of David's house and lineage)

2002 efterkommer af Kong David (decendants of King David)

1948 Og det skete medens, de var der, kom tiden, da hun skulle føde (And it happened, while they were there, came the time when she were to give birth)

2002 Da de nåede frem til Betlehem, kom tidspunktet, da hun skulle føde (When they reached Bethlehem, came the time when she were to give birth)

1948 Og hun fødte sin søn, den førstefødte (And she gave birth to her son, the firstborn)

2002 Maria fik sit første barn - en dreng (Maria had her first child - a boy)

1948 herberget (the inn)

2002 kroen (more contemporary word for an inn)

The denotative content of the text remains the same as in the 1948 edition. The changes made centre around the level of background knowledge and ability of comprehension of the target group. Old and complex expressions are replaced by simpler contemporary ones. The aim is to get the target group to accept the text as of contemporary relevance and to reduce the time spent reading and understanding the text.

\section{Case study results and discussion of results}

\subsection{Main parameters involved in intralingual translation}

On the basis of the case study and assisted by introspection and the more or less stray sentences of the literature referred to above, the main factors that seem to be influential in intralingual translation (and at the same time, the very reasons for the existence of intralingual translation) have been examined. These factors are:

- knowledge

- time

- culture

- space 
These four factors are not listed according to importance, as that depends on the kind of intralingual translation. Presumably more than one factor will have an impact in any given instance of intralingual translation and the boundaries between the factors are far from watertight - in this article, the categories have been used solely for explanatory purposes and they can, with no doubt, be further developed or regrouped. The next sections present a closer look at each of the parameters.

\subsubsection{Knowledge}

This parameter centres around the ability of comprehension of the target group, i.e., the target group's general ability to understand a text, its level of general background knowledge or its level of expertise (or lack of) in connection with a specific subject. This is evident, for instance, when looking at the everyday Danish version and the children's versions and is presumably the driving force in the majority of intralingual translations. The parameter of knowledge often involves interpretation (explicitation, explanation, addition) of information which may be objective (It can be very cold outside in the winter in Judaea [...]) or subjective (the political/feminist comments of the 1973 family Bible). In the latter case, the aim of the intralingual translation is no longer merely comprehension of the factual content of the text - there is also an element of expressivity/persuasion.

Typical intralingual translations instigated by the parameter of knowledge (explanatory translations) are typically of the expert-to-layman kind (patient package inserts containing information on medicine, tax leaflets based on new legislation, manuals for durable consumer goods) or children's versions (easy-readers) of classical texts.

\subsubsection{Time}

This parameter covers instances where it is the temporal distance which makes a new version necessary. The parameter of time is of course related to the parameters of culture and knowledge, but in this case it is the diachronic factor which results in the lack of knowledge or cultural understanding; this is the reason for the new authorised version from 1992, for example, and is an important element in the everyday version (even in cases where a reader is able to read and understand the old authorised version from 1948, it will take him less time to process the everyday version).

Intralingual translations instigated by the parameter of time (diachronic translations) are typically new and more contemporary translations of classical texts (religious texts, literature): "Every generation retranslates the classics, out of a vital compulsion for immediacy and precise echo" (Steiner 1975: 29-30). Steiner was particularly interested in intralingual translation which was diachronically motivated:

The schematic model of translation is one in which a message from a source-language passes into a receptor-language via a transformational process. The barrier is the obvious fact that one language differs from the other [...] Exactly the same model - and this is what is rarely stressed - is operative within a single language. But here the barrier or distance between source and receptor is time (Steiner 1975: 28).

The translation may be purely intralingual and solely rely on a former version in the same language or the source text may consist of both a former version and the original text (as is the case with the 1948 and 1992 authorised versions, for instance), 
thus involving intralingual as well as interlingual translation ${ }^{12}$. Or the translation is not in writing, but takes place automatically while we read and process the old text as Steiner (1975: 28) argues. ${ }^{13}$

\subsubsection{Culture}

The parameter of culture refers to the need to explain cultural references in a text which time or general background knowledge prevent the target group from understanding even though the languages involved are the same; this is the case in the everyday version and in the children's versions.

Intralingual translations instigated by the parameter of culture (intercultural translations) could typically be an American version of an English book (as is the case with Harry Potter, for instance, which has been published in a special American edition replacing cultural words like biscuits, football, Mummy, rounders and sherbet lemons with cookies, soccer, Mommy, baseball and lemon drops [Hatim and Munday 2004: 4-5]). At the EST 2004 conference in Lisbon (proceedings forthcoming), Denton dealt with intercultural translation in his paper "Waterlogged Somewhere in Mid-Atlantic: Why American Readers Need Intralingual Translation but Don't Often Get It." Rollason (2006: 5) refers to Denton who showed that even an English original can encounter communication barriers when crossing the Atlantic and exemplified with:

Sue Townsend's novel of 1982 The Secret Diary of Adrian Mole, Aged 13 3/4, a cult bestseller in Britain but far less successful in the US, where its very British cultural codes and slang terms have impeded readers' enjoyment, to the point where Denton even suggests the case points up the need for intralingual translation. A British book, then, can be "foreign" for American readers (Rollason 2006: 5).

Within the business world, another example of intercultural intralingual translation would be the phenomenon of localisation. Localisation is now a huge industry which does of course often involve translation proper, but in many cases localisation also takes place intralingually, the aim being to produce different cultural versions of the same text within the same language.

\subsubsection{Space}

The parameter of space refers to instances where the text is either reduced or extended, i.e., the physical space of the text is changed. In the children's versions, we see reduction as well as extension, but especially the latter.

Intralingual translations instigated by the parameter of space (reducing/extending translations) are typically various kinds of summarizing (such as précis-writing, shortened versions of classical texts such as easy-readers, news reporting or subtitling for the deaf (Snell-Hornby 2006: 21) or extension/addition, which is typically seen when explanation is needed due to comprehension limits in the target group caused by time, culture or lack of knowledge.

\subsection{Family resemblances? A comparison of interlingual and intralingual translation}

It is interesting to see how many of the microstrategies applied in the intralingual Bible translations resemble those commonly used when carrying out interlingual 
translation. Though this observation is rarely mentioned or discussed within translation studies, it is not surprising considering the fact that many of the strategies aim at ensuring maximum comprehension and in most cases, comprehension is a central aim in both kinds of translation. Many of the strategies used to create the different Bible versions are common within translation proper as well - this applies to strategies such as omission, objective addition, explicitation, restructuring and paraphrase. The similarities cannot be denied, they overlap and criss-cross - the family resemblance is definitely there. It may be more productive though to look at some of the differences.

\subsubsection{Differences between interlingual and intralingual translation}

On the face of it, the main difference between the two kinds of translation is the involvement in interlingual translation of two different national languages. The main obstacle to communication in interlingual translation, and thus the reason for the translational activity, is the fact that the target group of the translation would not understand the linguistic code in which the source text is written. However, in intralingual translation two codes are also involved; not the codes of national languages, but of different genres or target groups. It is a difference, but it is perhaps not as monumental as one might think. The codes of different discourse communities within the same language may be almost as different from each other as two different national languages (Kirkness 1997: 5).

The problem of synonymy in interlingual translation (how to establish the meaning of and choose between synonyms, whether to make use of loan words or calques, etc.) resembles the challenge within intralingual translation of transmitting the same message in the linguistic style of another genre e.g. by means of synonymous expressions of another level of formality as pointed out by Steiner (1975).

Apart from the obvious difference of the number of national languages involved, the most significant difference seems to be that in many kinds of intralingual translation simplification ${ }^{14}$ is the keyword. It also seems that the strategy of simplification is driven by one of the four parameters knowledge (e.g., layman words and expressions and simple active syntax substituted for expert terms and complex syntax, whereas syntactical changes in interlingual translation are often called for on the basis of structural differences between two languages), time (e.g., contemporary words and expressions and syntax substituted for obsolete words, expressions and syntax), culture (e.g., American words, expressions and syntax substituted for British words, expressions and syntax) or space (e.g., superfluous text omitted or explanatory text added) and that it takes many forms. As we have seen, it may take the form of considerable reduction of the text by leaving out what is deemed to be superfluous information in order to make the processing of the text easier. Alternatively, it may take the form of considerable addition to the text with the aim of explaining or making explicit difficult or implicit information. In order to simplify, the text may also be heavily paraphrased or restructured. In one of the Bible translations (for very small children), we saw that significant restructuring (i.e., restructuring which transgresses even paragraphs) had taken place to ease comprehension. As already pointed out, all strategies found in the intralingual versions are well-known within interlingual translation, but not necessarily with the aim of simplification and not to the extent seen in intralingual translation. This suggests that generally the difference in strategies between intralingual 
and interlingual translation is a question of degree and motivation rather than kind. The omissions, additions, restructuring, etc. seen in intralingual translation are more extreme than is generally the case in translation proper. It should be noted though that the general consensus today about the benefits of functional translations in many cases gives room for a much broader perception of what constitutes translation. That is, strategies applied within interlingual translation today in accordance with the skopos of the translation brief (e.g., a certain amount of restructuring or reduction) may 20 years ago have been considered unacceptable and beyond the tools available to translation proper. In principle, functional translation theory has narrowed the gap between intralingual and interlingual translation. However, it is suggested that the de facto degree of freedom is larger in intralingual translation than in most instances of translation proper. In addition, this may entail that there is also more room for interpretation, and perhaps even a certain degree of subjectivity, in intralingual translation (the extremely subjective additions in the family Bible would certainly not be deemed acceptable in interlingual translation, but probably not in the majority of intralingual translations either!), but the hypothesis will not be explored further in this article.

\section{Conclusion}

At one of the rare occasions when intralingual translation is commented on in translation literature, Steiner (1975: 260-61) pointed out that the two kinds of translation raise issues of the same order and are, at crucial points, similar. I completely agree, and this is why I think that by neglecting a whole strand of translation activities (which may not be translation proper but which nevertheless share strong family resemblances), we lose out on useful insights. At the same time, it should be added that though no one can deny that the resemblances are there it is also necessary to focus on the differences, or possible differences, between the two kinds of translation. If we know more about differences as well as similarities, the insights provided by both fields would be more useful.

The empirical work of this article is considered as a first attempt of a concrete, general description of the characteristics of and the microstrategies involved in intralingual translation. The analyses suggest that intralingual translation is generally motivated by one or more of the key parameters; knowledge, time, culture, and space. The most interesting findings of the analyses and of the comparison with interlingual translation is firstly the strong tendency of intralingual translation to involve a form of simplification - a strategy which is not so often applied as the overall skopos of a translation proper. Secondly and because of the purpose of simplification, the microstrategies applied in intralingual translation (the additions, omissions, restructuring, etc.) seem to be much more radical than what is seen in the majority of interlingual translations. In other words, the differences in microstrategies are more a question of degree than of kind.

In Denmark, and presumably in many other countries, there is an ever-increasing demand that expert knowledge be made accessible to the general public. Consumers, patients, taxpayers, etc. no longer tolerate incomprehensible expert texts. There is a huge demand for expert-to-layman translation as most experts find it difficult to write about their field in layman terms. In my view, translators are excellently 
equipped to carry out this kind of intralingual translation because of the many similarities with interlingual translation. In the practical and especially the didactic world, a too narrow definition of the field only sets an artificial boundary for translators and the jobs they see themselves as able to carry out. The professional translator and cultural mediator of today needs a large number of skills "to qualify as an expert for interlingual and intercultural communication” (Snell-Hornby 1999: 164). I would like to think that intralingual skills are included in the term intercultural communication, if we do not limit our definition of intercultural to mainly a question of national culture (see Zethsen 2010 forthcoming). On the basis of the above, I therefore encourage translation scholars to carry out research within the field. The analyses on which this article is based were carried out on a limited number of texts and the characteristics found cannot necessarily be generalised to all kinds of intralingual translation. I do believe, however, that they point in the right direction, but we need much more empirically-based research to provide a thorough and comprehensive description of intralingual translation and of the similarities and differences between intralingual and interlingual translation. It would furthermore be interesting to investigate who carry out intralingual translations in real life, what kind of source texts they are based on and in which ways the relationship between the source text and the target text may differ between intralingual and interlingual translation? Questions abound - I hope the future will see some answers.

\section{NOTES}

1. "All utterances which are presented or regarded as such within the target culture, on no matter what grounds" (Toury 1995: 32).

2. The Source Text Postulate, The Transfer Postulate and the Relationship Postulate (Toury 1995: 33-35).

3. Tymoczko $(1998,2005)$ is not particularly concerned with intralingual translation, but her arguments for a broad perception of translation are very relevant.

4. Bibelen (1948): (The 1948 Danish authorised version of the Bible.) Copenhagen: Det Danske Bibelselskab.

5. Bibelen (1992): (The 1992 Danish authorised version of the Bible.) Viborg: Det Danske Bibelselskab.

6. Holy Bible (1611/1986): Authorised King James version. USA: P.S.I. \& Associates, Inc. The numbers refer to the verse numbers.

7. Seidelin, Anna Sophie (1973): Hjemmenes Billedbibel (A family picture Bible from 1973). Vienna:Lademann.

8. Møllehave, Johannes (1991): Alle børns Bibel. (A picture Bible for very small children.) USA: Sesam.

9. Ny Testamente på hverdagsdansk (1985/2002): (The New Testament in everyday Danish.) Viborg: Scandinavia.

10. See also Shavit (1986) on the translation/transfer of children's literature.

11. "Man kan ikke blindt oversætte kildesprog til modtagersprog uden at forstyrre den oprindelige mening. Vi erkender derfor vort ansvar i den redaktionelle bearbejdning af grundteksten... Oversættelsen er således en fri oversættelse, ikke en ord-for-ord oversættelse, ej heller en parafrase."

12. For explanatory purposes, Jakobson's definition sets the two kinds of translation apart (though both are defined as examples of a translational activity). These separate definitions do of course not mean that both types cannot be at play in the same text or instance of translation - an element of intralingual translation may well be part of the skopos of an interlingual translation (see examples in Zethsen forthcoming). Toury (1986: 1113) mentions 
interdialectal translation as a borderline case and also Pym (1992: 25) argues that there is no strict cut-off point.

13. See also Weissbrod (2004: 27) on translation/transfer over time.

14. It cannot be entirely ruled out that intralingual translation in some instances may go from simple to more complex. An example could be a student who is asked to rewrite an essay and make it more formal, more academic. An assistant who is asked to rewrite a report, make it more complex, insert expert terms, etc. to make it more authoritative.

\section{REFERENCES}

BAKer, Mona, ed. (1998): Routledge Encyclopedia of Translation Studies. London: Routledge.

Dam-Jensen, Helle and Zethenen, Karen Korning (2007): Pragmatic patterns and the lexical system - a reassessment of evaluation in language. Journal of Pragmatics. 39(9):1608-1623.

Dam-Jensen, Helle and Zethsen, Karen Korning (2008): Translator awareness of semantic prosodies. Target. 20(2): 203-221.

Denton, John (2007): Waterlogged Somewhere in Mid-Atlantic: Why American Readers Need Intralingual Translation but Don't Often Get It. TTR. 20(2):243-270.

Even-Zohar, Itamar (1990): Polysystem Studies, a special issue of Poetics Today 11(1). Durham: Duke University Press.

GAMBier, Yves (1992): La reformulation - pratique intralinguistique et interlinguistique. Koïné. 1-2(2):291-314.

GutT, Ernst-August (1991/2000): Translation as interlingual interpretive use. In: Lawrence Venuti, ed. The Translation Studies Reader. London: Routledge, 376-396.

Hatim, Basil and Munday, Jeremy (2004): Translation: An Advanced Resource Book. London: Routledge.

HoLmes, James S. (1972/2000): The name and nature of translation studies. In: Lawrence VenUTI, ed. The Translation Studies Reader. London: Routledge, 172-185.

JаковSON, Roman (1959/2000): On linguistic aspects of translation. In: Lawrence Venuti, ed. The Translation Studies Reader. London: Routledge, 113-118.

Jeppesen, Knud (1990): Problemer ved at oversætte Bibelen til dansk på ny. Hermes. 5:15-33.

Kirkness, Alan (1997): Eurolatin and English today. English Today. 13(1):3-8.

Newmark, Peter (1981): Approaches to Translation. London: Pergamon Press.

Newmark, Peter (1999): Taking a stand on Mary Snell-Hornby. Current Issues in Language and Society. 6(2):152-154.

Nicolson, Adam (2003/2004): Power and Glory. Jacobean England and the making of the King James Bible. London: Harper Perennial.

Pyм, Anthony (1992): Translation and Text Transfer: An Essay on the Principles of Intercultural Communication. Frankfurt am Main: Peter Lang.

Rollason, Christopher (2006): Beyond the domestic and the foreign: translation as dialogue. Visited on June $17^{\text {th }}, 2009$. <http://www.seikilos.com.ar/TranslationDialogue.pdf >.

Rosch, E. (1973): On the internal structure of perceptual and semantic categories. In: Timothy E. Moore, ed. Cognitive Development and the Acquisition of Language. New York: Academic Press, 114-144.

SChÄffner, Christina (1999): Globalisation, Communication, Translation. Current Issues in Language and Society. 6(2):93-102.

Shavit, Zohar (1986): Poetics of Children's Literature. Athens: The Univeristy of Georgia Press.

Shuttleworth, Marc (1997): Dictionary of Translation Studies. Manchester: St Jerome Publishing.

Snell-Hornby, Mary (1988): Translation Studies. An Integrated Approach. Amsterdam: John Benjamins.

SNeLL-Hornby, Mary (1999): Communicating in the Global Village: On Language, Translation and Cultural Identity. Current Issues in Language and Society. 6(2):103-120.

Snell-Hornby, Mary (2006): The Turns of Translation Studies. Amsterdam: John Benjamins. 
Steiner, George (1975): After Babel: Aspects of Language and Translation. London: Oxford University Press.

Toury, Gideon (1985): A rationale for descriptive translation studies. In: Theo Hermans, ed. The Manipulation of Literature. Studies in Literary Translation. London: Croom Helm, 16-41.

Toury, Gideon (1986): Translation: a cultural-semiotic perspective. In: Thomas A. SeBEoK, ed. Encyclopaedic Dictionary of Semiotics. Vol. 2. Berlin: Mouton de Gruyter, 1111-1124.

Toury, Gideon (1995): Descriptive Translation Studies and Beyond. Amsterdam: John Benjamins. түмосzко, Maria (1998): Computerized corpora and the future of translation studies. Meta. 48(4):1-9.

Tүмосzко, Maria (2005): Trajectories of Research in Translation Studies. Meta. 50(4):1082-1097.

Weissbrod, Rachel (1998): Translation Research in the Framework of the Tel Aviv School of Poetics and Semiotics. Meta 43(1), 35-45.

Weissbrod, Rachel (2004): From Translation to Transfer. Across Languages and Cultures. 5(1):23-41.

Wittgenstein, Ludwig (1953/1958): Philosophical Investigations. Oxford: Blackwell.

Zethsen, Karen Korning (2004): Latin-based terms: True or false friends? Target. 16(1):125-142.

ZethSEN, Karen Korning (2008): Beyond translation proper - extending the field of translation studies. TTR. 20(1): 281-308

Zethsen, Karen Korning (forthcoming): Has globalisation unburdened the translator. Meta. 